\title{
HOSPTALIZATION AND IN-HOSPITAL MORTALITY DUE TO COVID-19 IN THE SILESIAN VOIVODESHIP DURING THE FIRST YEAR OF EPIDEMIC
}

\author{
CHOROBOWOŚĆ HOSPITALIZOWANA I ŚMIERTELNOŚĆ WEWNĄTRZSZPITALNA \\ Z POWODU COVID-19 W WOJEWÓDZTWIE ŚLĄSKIM \\ W PIERWSZYM ROKU EPIDEMII
}

\author{
${ }^{1}$ Department of Epidemiology, Faculty of Medical Sciences in Katowice, \\ Medical University of Silesia, Katowice \\ Katedra i Zakład Epidemiologii, Wydział Nauk Medycznych w Katowicach, \\ Śląski Uniwersytet Medyczny w Katowicach \\ ${ }^{2}$ Department of Epidemiology and Biostatistics, Faculty of Health Sciences in Bytom, \\ Medical University of Silesia, Katowice \\ Katedra Epidemiologii i Biostatystyki, Wydział Nauk o Zdrowiu w Bytomiu, \\ Śląski Uniwersytet Medyczny w Katowicach
}

\begin{abstract}
INTRODUCTION. The Silesian Voivodeship is the region with the highest population density in Poland, three times higher than the national average. These are important circumstances that may favor the transmission of the SARS-CoV-2 virus and, due to the severe course of the disease in many patients, contribute to overloading the healthcare system.

AIM. The aim of the study was to evaluate the temporal and territorial variability of hospitalized morbidity and in-hospital mortality in COVID-19 patients treated in the study region.

MATERIAL AND METHODS. The research was an epidemiological descriptive study. Secondary epidemiological data were obtained from the registry of the Health Department of the Silesian Voivodeship Office in Katowice. Crude and standardized hospitalized morbidity rates, as well as COVID-19 in-hospital mortality, were calculated. Results were presented in particular poviats and subsequent months of the 2020 year. The capabilities of the ArcGIS 9.2 geographic information system and Statistica 13.3 software were used.

RESULTS. The largest number of patients hospitalized due to COVID-19 and the number of deaths occurred in autumn and spring, in both periods in-hospital mortality was over $24 \%$. The poviats with the highest standardized hospitalized prevalence rate were located in the southern part of the Silesian Voivodeship. The highest in-hospital mortality (exceeding 24\%) was recorded in Gliwice, Mysłowice, Tychy, Bytom and in the Lubliniec poviat. Older people (65+), usually with diagnosed comorbidities, including chronic respiratory and cardiovascular diseases, died more often.

CONCLUSIONS. The highest number of patients and deaths due to COVID-19 occurred in autumn. A significant territorial diversification of hospitalized morbidity and in-hospital mortality was demonstrated, the worst situation concerned densely populated poviats and cities. Worse prognosis applied to older patients with comorbidities.
\end{abstract}

Keywords: COVID-19, hospitalization, hospitalized morbidity, in-hospital mortality, comorbidities, health maps 


\section{STRESZCZENIE}

WSTĘP. Województwo śląskie jest regionem o największej gęstości zaludnienia w Polsce, 3-krotnie większej niż średnia dla kraju. To ważne okoliczności, które mogą sprzyjać transmisji wirusa SARS-CoV-2, a z uwagi na ciężki przebieg choroby u wielu pacjentów, przyczyniają się do przeciążenia systemu opieki zdrowotnej.

CEL PRACY. Celem pracy była ocena czasowej i terytorialnej zmienności chorobowości hospitalizowanej i śmiertelności wewnątrzszpitalnej pacjentów leczonych w szpitalach woj. śląskiego z powodu COVID-19.

MATERIAŁ I METODY. Badanie miało charakter epidemiologicznego badania opisowego. Źródłem danych był rejestr Wydziału Zdrowia Śląskiego Urzędu Wojewódzkiego w Katowicach. Obliczono surowe i standaryzowane współczynniki chorobowości hospitalizowanej, a także śmiertelność wewnątrzszpitalną z powodu COVID-19. Zaprezentowano je w poszczególnych powiatach i kolejnych miesiącach 2020 roku. Wykorzystano możliwości systemu informacji geograficznej ArcGIS 9.2 oraz oprogramowania Statistica 13.3.

WYNIKI. Największa liczba chorych hospitalizowanych z powodu COVID-19 oraz liczba zgonów dotyczyła jesieni i wiosny, w obydwu przypadkach śmiertelność wewnątrzszpitalna kształtowała się na poziomie ponad 24\%. Powiaty o największym standaryzowanym współczynniku chorobowości hospitalizowanej były zlokalizowane w południowej części woj. śląskiego. Największą śmiertelność wewnątrzszpitalną (przekraczającą 24\%) odnotowano w Gliwicach, Mysłowicach, Tychach, Bytomiu oraz w powiecie lublinieckim. Częściej umierały osoby starsze (+65 lat), zazwyczaj z rozpoznanymi chorobami towarzyszącymi, wśród których dominowały przewlekłe choroby układu oddechowego i krążenia.

WNIOSKI. Największa liczba chorych i zgonów z powodu COVID-19 dotyczyła jesieni. Wykazano znaczne zróżnicowanie terytorialne chorobowości hospitalizowanej i śmiertelności wewnątrzszpitalnej, najgorsza sytuacja dotyczyła powiatów i miast gęsto zaludnionych. Gorsze rokowanie mieli chorzy starsi z wielochorobowością.

Słowa kluczowe: COVID-19, hospitalizacje, chorobowość hospitalizowana, śmiertelność wewnatrzszpitalna, choroby wspótistniejace, mapy zdrowia

\section{INTRODUCTION}

We have been struggling with an epidemic of acute infectious respiratory disease caused by the SARSCoV-2 virus (Severe acute respiratory syndrome, coronavirus 2) since the beginning of 2020 (1). The World Health Organization declared the state of the COVID-19 pandemic (Coronavirus Disease 2019) in a relatively short period and following this decision, the governments of individual countries took appropriate preventive actions. The first decisions were made in Poland in March 2020 and concerned, inter alia, suspension of the functioning of educational institutions and universities, then closing the borders of the country, and introducing the 'state of the epidemic' (2). In intention, mentioned restrictions and recommendations were supposed to reduce the number of new infections and to support the overloaded healthcare system.

It is important to determine the causes and sources of new infections and to eliminate the serious consequences of the disease in the population, in particular, regarding infectious diseases. It is not possible without a proper diagnosis of the epidemiological situation. Usually, to assess the health status of the population in public health are used secondary epidemiological data such as the

\section{WSTĘP}

Począwszy od pierwszych dni 2020 roku zmagamy się z epidemią ostrej choroby zakaźnej układu oddechowego wywołanej wirusem SARS-CoV-2 (Severe acute respiratory syndrome coronavirus 2) (1). W stosunkowo krótkim czasie Światowa Organizacja Zdrowia ogłosiła stan pandemii COVID-19 (Coronavirus disease 2019), a w ślad za tą decyzją rządy poszczególnych państw podjęły stosowne działania zapobiegawcze. Pierwsze decyzje zaczęto podejmować w Polsce w połowie marca 2020 roku. Dotyczyły one m.in. zawieszenia funkcjonowania placówek oświatowych i uczelni wyższych, następnie zamknięto granice państwa, wprowadzono tzw. „stan epidemii” na terenie całego kraju (2). W zamierzeniu, wprowadzone ograniczenia i zalecenia sanitarno-epidemiologiczne miały zmniejszyć liczbę nowych zakażeń i wspomóc przeciążony system opieki zdrowotnej.

Szczególnie w odniesieniu do chorób zakaźnych ważne jest ustalenie przyczyn i źródła nowych zakażeń oraz eliminacja poważnych następstw choroby w populacji, co nie jest możliwe bez właściwego rozpoznania sytuacji epidemiologicznej. Zazwyczaj najprostszym sposobem oceny jest analiza wtórnych danych epidemiologicznych dotyczących m.in. liczby zachorowań, hospitalizacji, ale także liczby zgonów przypisanych 
number of cases, hospitalizations, but also the number of deaths. The obtained data are delayed e.g., due to the necessity of their verification and introduction to the electronic system. One of such registers in Poland is the IT system "Statistical Card Analysis" administered, among others, by the Silesian Voivodeship Office in Katowice (3). It enables tracking temporal and spatial variability inhospital morbidity and mortality of patients treated for underlying diseases, including COVID-19. It is possible to determine the age and sex of all patients hospitalized in the voivodeship, the time and place of hospitalization, including the poviat, but also coexisting diseases, and discharge mode from the hospital (including death). The current MZ/Szp-11 form used in the Polish registry with appropriate instruction was published in the Journal of Laws (2017) (4).

The Silesian Voivodeship is a region with 4.5 million inhabitants and the highest density of population in Poland (366 people $/ \mathrm{km}^{2}$, while the average for Poland equals $123 / \mathrm{km}^{2}$ ) (5). Mentioned circumstances are very important to the epidemiology of respiratory infectious diseases. The high density of population may increase the transmission of the virus and contribute to the overloading of the health care system, including hospital care, which had problems even before the pandemic (6).

\section{AIM}

The aim of the presented study is to assess the temporal and spatial variability in hospitalized morbidity and in-hospital mortality of COVID-19 patients in the Silesian Voivodeship, in 2020.

\section{MATERIAL AND METHODS}

Assessment of the epidemiological situation was based on secondary epidemiological data obtained during the project aimed at recognizing the frequency, course, and risk factors of SARS-CoV-2 infection in the population of the Upper Silesian Agglomeration and financed by the Medical Research Agency in Warsaw (7). The source of necessary data was the registry of 'Statistical Card Analysis' administrated by the Silesian Voivodeship Office in Katowice, Health Department - Department for Monitoring, Analyzes, and Medical Statistics. The completeness of the registry in the Silesian Voivodeship is at the level of $99.9 \%$. In the descriptive type of study, data obtained from March 1 to December 31, 2020, and containing information of sex, age, place of residence (poviat), comorbidities, and discharge procedure were analyzed. The analyzes included separate months, chorobie. Pozyskiwane dane są ujawniane z pewnym opóźnieniem m.in. z uwagi na konieczność ich weryfikacji i wprowadzenia do systemu elektronicznego. Jednym $\mathrm{z}$ takich rejestrów jest informatyczny system „Analiza Kart Statystycznych” prowadzony m.in. przez Śląski Urząd Wojewódzki w Katowicach (3). Umożliwia on śledzenie czasowej i terytorialnej zmienności w zakresie chorobowości hospitalizowanej i śmiertelności wewnątrzszpitalnej pacjentów leczonych z powodu choroby zasadniczej, a więc także $\mathrm{z}$ powodu COVID-19. Jest możliwe określenie wieku i płci osób leczonych we wszystkich szpitalach danego województwa, czasu i miejsca zdarzenia $\mathrm{z}$ uwzględnieniem powiatu, ale również chorób współistniejących i trybu wypisu ze szpitala (ze zgonem włącznie). Aktualny wzór formularza MZ/Szp-11 karty statystycznej szpitalnej ogólnej wraz z instrukcją jego wypełniania określono stosownym Dziennikiem Ustaw w 2017 roku (4).

Województwo śląskie jest regionem, w którym mieszka 4,5 mln ludności, a gęstość zaludnienia jest jedną z największych w Polsce (366 osób/ $\mathrm{km}^{2}$ przy średniej dla Polski $123 / \mathrm{km}^{2}$ ) (5). To z punktu widzenia epidemiologii chorób zakaźnych układu oddechowego ważne okoliczności, które mogą sprzyjać transmisji wirusa i przyczyniają się do obciążenia funkcjonującego systemu opieki zdrowotnej, w tym opieki szpitalnej, która miała problemy już przed pandemią (6).

\section{CEL PRACY}

Celem prezentowanej pracy jest ocena czasowej i terytorialnej zmienności w zakresie chorobowości hospitalizowanej i śmiertelności wewnątrzszpitalnej pacjentów leczonych $\mathrm{z}$ powodu COVID-19 w woj. śląskim, w 2020 roku.

\section{MATERIAŁ I METODY}

W ramach grantu ukierunkowanego na rozpoznanie częstości, przebiegu i czynników ryzyka zakażenia wirusem SARS-CoV-2 w populacji Aglomeracji Górnośląskiej finansowanego ze środków Agencji Badań Medycznych w Warszawie (7) dokonano oceny sytuacji epidemiologicznej na podstawie wtórnych danych epidemiologicznych. Dla realizacji założonego celu pracy zebrano dane zawarte w rejestrze „Analiza Kart Statystycznych" prowadzonym przez Śląski Urząd Wojewódzki w Katowicach, Wydział Zdrowia - Oddział do Spraw Monitorowania, Analiz i Statystyki Medycznej. Kompletność danych rejestrowych dla województwa śląskiego kształtuje się na poziomie $99,9 \%$. W modelu badania opisowego, opracowano dane zarejestrowane w okresie od 1 marca do 31 grudnia 2020 roku i zawierające następujące informacje: płeć, wiek, miejsce zamieszkania (powiat), choroby współistniejące i tryb 
taking into account the dates of discharge after the completed treatment process in a given hospital. Then, the results were presented as the cumulated values for the entire period (from March to the end of December). Mean values were calculated for the age of the deceased and for those who survived the treatment. The hospitalized morbidity in the analyzed period was presented using the crude rates calculated as the cumulative number of hospitalizations to the number of inhabitants per 100,000 population (8). Then, the hospitalized morbidity rates were standardized using the European population as a reference standard (9). In-hospital mortality rates were calculated taking into account the percentage of the number of deaths to the number of patients hospitalized due to COVID-19.

The study is not a medical experiment and the depersonalized nature of the collected data did not require the approval of the Bioethics Committee. The spatial variability of the number of hospitalized and deceased patients in separate local administrative units of the Silesian Voivodeship according to NTS4 and NTS-5 (Nomenclature of Territorial Units for Statistical Purposes) was also investigated, taking into account the division into 36 poviats and 167 communes, respectively. Statistica 13.3 software (descriptive data, difference tests, and correlation analysis) and the ArcGIS 9.2 geographic information system (spatial variability) were used in the analysis. The results were presented as an arithmetic mean and standard deviation $(\mathrm{X} \pm \mathrm{SD})$ for quantitative variables, and qualitative variables as number and percentage (n, \%). The compatibility with the normal distribution was tested by the Shapiro-Wilk test. The Mann-Whitney U-test was used to assess the differences of quantitative variables and the $\mathrm{Chi}^{-}$ square test for qualitative variables. The correlation coefficient R Pearson or R' Spearman was used to assess relationships between compared variables, depending on the form of distribution. Statistical significance was based on the criterion $\mathrm{p}<0.05$.

\section{RESULTS}

17,003 hospitalizations due to the main diagnosis of COVID-19 (code U07 according to ICD-10) were registered in the Silesian Voivodeship in 2020, where $82.5 \%$ of patients $(n=14,025)$ were identified based on the molecular test RT-PCR (code U07.1 according to ICD-10), while $17.5 \%$ of patients $(n=2,978)$ were diagnosed based on clinical symptoms or the epidemiological criteria (code U07.2 according to ICD-10). 2,968 COVID-19 patients died, which is $17.5 \%$ of all hospitalized for this reason. The obtained results indicate that COVID-19 epidemic in 2020 had wypisu. Analizy prowadzono odrębnie dla każdego miesiąca, uwzględniając daty wypisów po zakończonym procesie leczenia w danej jednostce szpitalnej, a następnie wyniki zaprezentowano w postaci wartości skumulowanych dla całego okresu rocznego (od marca do końca grudnia). Wyznaczono wartości średnie dla wieku osób zmarłych i tych, które przeżyły leczenie. Chorobowość hospitalizowaną w badanym okresie przedstawiono za pomocą surowych współczynników obliczonych jako skumulowane liczby hospitalizacji w odniesieniu do liczby ludności i zaprezentowano w postaci współczynnika na 100000 ludności (8). Następnie, zgodnie z zaleceniami WHO, dokonano standaryzacji współczynników chorobowości hospitalizowanej wykorzystując jako wzorzec europejską populację standardową (9).

Badanie nie jest eksperymentem medycznym, a odpersonalizowany charakter zebranych danych nie wymagał zgody Komisji Bioetycznej. Dla zmiennych jakościowych wyznaczono wartości odsetkowe, obliczono współczynniki śmiertelności wewnątrzszpitalnej biorąc pod uwagę procentowy udział liczby zgonów w odniesieniu do liczby pacjentów hospitalizowanych z powodu COVID-19. Prześledzono również zmienność terytorialną liczby chorych hospitalizowanych i zmarłych w odrębnych lokalnych jednostkach administracyjnych województwa śląskiego wg NTS-4 i NTS-5 (Nomenklatura Jednostek Terytorialnych do Celów Statystycznych) z uwzględnieniem podziału odpowiednio na 36 powiatów i 167 gmin. W analizach zastosowano oprogramowanie Statistica 13.3 (dane opisowe, testy różnic, analiza korelacji) oraz system informacji geograficznej ArcGIS 9.2 (dla prezentacji zmienności terytorialnej). Wyniki zaprezentowano w postaci średniej arytmetycznej i odchylenia standardowego $(\mathrm{X} \pm \mathrm{SD})$, a dla zmiennych jakościowych liczbę i odsetek (n, \%). Zgodność $z$ rozkładem normalnym badano testem Shapiro-Wilka. Dla oceny zróżnicowania zmiennych ilościowych wykorzystano test U-Manna Whitney'a, a dla zmiennych jakościowych test $\mathrm{Chi}^{2}$. Do oceny zależności wskaźników ilościowych wykorzystano w zależności od postaci rozkładu współczynnik korelacji R Pearsona lub R' Spearmana wraz z odpowiednim testem istotności. Wnioskowanie statystyczne oparto o kryterium istotności $\mathrm{p}<0,05$.

\section{WYNIKI}

W województwie śląskim, w roku 2020 zarejestrowano łącznie 17003 hospitalizacje z powodu głównego rozpoznania COVID-19 (kod U07 wg ICD-10), przy czym $82,5 \%$ chorych $(n=14025)$ zostało zidentyfikowanych na podstawie badania laboratoryjnego (badanie molekularne metodą RT-PCR) (kod U07.1 wg ICD-10), natomiast $17,5 \%$ chorych $(n=2978)$ rozpoznano na pod- 
three periods characterized by a slightly different epidemiological situation: the first wave (MarchJune), summer (July-September), and the second wave (October-December) - Table I.

Particular variability is especially visible in the case of in-hospital mortality, calculated as the percentage of deaths among patients hospitalized due to COVID-19. The highest value concerned patients hospitalized in November (24.8\%) and March (24.3\%), while the lowest was recorded in summer (July, respectively 4.6\%). A significant increasing trend in the average age of the total number of hospitalized patients $(\mathrm{R}=0.79, \mathrm{p}=0.007)$ was documented in the analyzed period, while the mean age of deceased patients remained constant $(\mathrm{R}=0.09, \mathrm{p}=0.81)$. stawie objawów klinicznych lub kryteriów epidemiologicznych (kod U07.2 wg ICD-10). 2968 osób hospitalizowanych zmarło, co stanowi 17,5\% wszystkich osób leczonych w szpitalach z powodu COVID-19. Uzyskane wyniki wskazują, iż w trakcie 2020 roku można wyróżnić trzy okresy charakteryzujące się nieco odmienną sytuacją epidemiologiczną choroby: pierwsza fala zachorowań (marzec-czerwiec), lato (lipiec-wrzesień) oraz druga fala zachorowań (październik-grudzień) Tabela I.

Szczególne zróżnicowanie widoczne jest w odniesieniu do śmiertelności wewnątrzszpitalnej liczonej jako odsetek zgonów wśród pacjentów hospitalizowanych z powodu COVID-19. Największy odsetek zgonów dotyczył pacjentów hospitalizowanych w listopadzie $(24,8 \%)$ oraz w marcu $(24,3 \%)$, zdecydowanie najmniejsze wartości odnotowano latem (lipiec - 4,6\%). $\mathrm{W}$ badanym okresie udokumentowano znamienny trend rosnący uśrednionego wieku ogółu osób hospitalizowanych $(\mathrm{R}=0,79 ; \mathrm{p}=0,007)$, podczas gdy średni wiek osób, które zmarły pozostawał na stałym poziomie $(\mathrm{R}=0,09$; $\mathrm{p}=0,81)$.

Table I. Statistics of hospitalizations and in-hospital mortality due to COVID-19 in Silesian Voivodship in the following months of 2020

Tabela I. Statystyka hospitalizacji i zgonów z powodu COVID-19 w woj. śląskim w kolejnych miesiącach 2020 roku

\begin{tabular}{|c|c|c|c|c|c|}
\hline \multirow[t]{2}{*}{$\begin{array}{l}\text { Rok } 2020 \text { / } \\
\text { Year } 2020\end{array}$} & \multirow{2}{*}{$\begin{array}{l}\text { Liczba hospitali- } \\
\text { zowanych / } \\
\text { Number } \\
\text { of hospitalized } \\
n(\%)\end{array}$} & \multirow{2}{*}{$\begin{array}{l}\text { Liczba zgonów / } \\
\text { Number of } \\
\text { deaths } \\
\mathrm{n}(\%)\end{array}$} & \multirow{2}{*}{$\begin{array}{l}\text { Śmiertelność } \\
\text { wewnątrzszpi- } \\
\text { talna / } \\
\text { in-hospital } \\
\text { mortality (\%) }\end{array}$} & \multicolumn{2}{|c|}{$\begin{array}{c}\text { Średni wiek pacjentów w } \\
\text { momencie [lata] / } \\
\text { Average age of patients in moment } \\
\text { of [years] }\end{array}$} \\
\hline & & & & $\begin{array}{l}\text { Wypisu / } \\
\text { Discharge }\end{array}$ & $\begin{array}{l}\text { Zgonu / } \\
\text { Death }\end{array}$ \\
\hline Marzec / March & $37(0,2)$ & $9(0,3)$ & 24,3 & $52,1 \pm 20,7$ & $72,3 \pm 9,9$ \\
\hline Kwiecień / April & $461(2,7)$ & $95(3,2)$ & 20,6 & $58,2 \pm 17,4$ & $76,0 \pm 11,6$ \\
\hline Maj / May & $1032(6,1)$ & $99(3,3)$ & 9,6 & $56,3 \pm 19,2$ & $73,2 \pm 11,6$ \\
\hline Czerwiec / June & $1302(7,7)$ & $122(4,1)$ & 9,4 & $55,0 \pm 19,7$ & $72,4 \pm 12,9$ \\
\hline Lipiec / July & $1214(7,1)$ & $56(1,9)$ & 4,6 & $58,0 \pm 20,6$ & $73,9 \pm 12,7$ \\
\hline Sierpień / August & $1232(7,2)$ & $91(3,1)$ & 7,4 & $57,7 \pm 20,8$ & $75,7 \pm 11,1$ \\
\hline Wrzesień / September & $944(5,6)$ & $65(2,2)$ & 6,9 & $61,0 \pm 20,8$ & $73,2 \pm 13,2$ \\
\hline Październik / October & $2225(13,1)$ & $448(15,1)$ & 20,1 & $60,9 \pm 19,4$ & $75,9 \pm 10,7$ \\
\hline Listopad / November & $4557(26,8)$ & $1128(38,0)$ & 24,8 & $66,2 \pm 14,4$ & $73,5 \pm 11,6$ \\
\hline Grudzień / December & $3999(23,5)$ & $855(28,8)$ & 21,4 & $65,1 \pm 16,1$ & $74,4 \pm 11,3$ \\
\hline Ogółem / Total & $17003(100)$ & $2968(100)$ & 17,5 & $61,1 \pm 18,3$ & $74,4 \pm 11,5$ \\
\hline
\end{tabular}

The analysis of the discharge data shows that more than half of the patients were recommended for further treatment $(28.1 \%$ outpatient treatment, $25.2 \%$ treatment in a different ward, and $8.3 \%$ referral to another hospital). Indirectly, this indicates the serious consequences of the disease that require further medical attention (Table II).
Analiza danych dotyczących trybu wypisu wskazuje, że w odniesieniu do ponad połowy chorych wystawiono skierowanie do dalszego leczenia $(28,1 \%$ leczenie ambulatoryjne, $25,2 \%$ leczenie $\mathrm{w}$ innym oddziale, $8,3 \%$ skierowanie do innego szpitala). W pewien sposób wskazuje to na poważne skutki choroby, które wymagają dalszej pomocy medycznej (Tabela II). 
Table II. Number and percentage of hospitalized patients, according to type of discharge in Silesian Voivodship in 2020 Tabela II. Liczba i odsetek hospitalizowanych pacjentów z uwzględnieniem trybu wypisu, w woj. śląskim w 2020 roku

\begin{tabular}{|c|c|}
\hline Tryb wypisu ze szpitala / Type of hospital discharge & $\begin{array}{c}\text { Liczba hospitalizowanych/ } \\
\text { Number of hospitalized } \\
\text { n (\%) }\end{array}$ \\
\hline $\begin{array}{c}\text { Skierowanie do leczenia ambulatoryjnego / } \\
\text { Referral to outpatient treatment }\end{array}$ & $4782(28,1)$ \\
\hline $\begin{array}{c}\text { Zakończenie leczenia lub diagnostyki / } \\
\text { End of treatment or diagnostics process }\end{array}$ & $3437(20,2)$ \\
\hline $\begin{array}{c}\text { Skierowanie do innego szpitala / } \\
\text { Referral to another hospital }\end{array}$ & $1408(8,3)$ \\
\hline $\begin{array}{c}\text { Skierowanie na inny oddział / } \\
\text { Referral to another department }\end{array}$ & $4289(25,2)$ \\
\hline Zgon / Death & $2968(17,5)$ \\
\hline $\begin{array}{c}\text { Samowolne opuszczenie zakładu lub wypis na żądanie / } \\
\text { Arbitrary leaving or requested discharge }\end{array}$ & $119(0,7)$ \\
\hline Ogółem / Total & $17003(100)$ \\
\hline
\end{tabular}

There was a slight predominance of men among hospitalized patients, 9,511 (55.5\%) men, and 7,492 (44.1\%) women, respectively. The mean age of the patients was $63.8 \pm 18.2$ years, with less than half of the hospitalized patients $(\mathrm{n}=7,382 ; 43.4 \%)$ under the age of 65 (including 414 children; 2.4\%). More than half of patients treated for COVID-19 in Silesian Voivodeship hospitals were people aged 65 and over $(n=9,615$; $56.6 \%$ ). The youngest patients were newborn children and the oldest patient was 102 years old. A detailed demographic structure is presented in Figure 1. The mean age of deceased patients hospitalized due to COVID-19 was significantly higher than the age of
Odnotowano niewielką przewagę mężczyzn wśród osób hospitalizowanych, odpowiednio 9511 (55,5\%) mężczyzn i 7492 (44,1\%) kobiet. Średni wiek chorych wynosił $63,8 \pm 18,2$ lat, przy czym niespełna połowa hospitalizowanych ( $\mathrm{n}=7382 ; 43,4 \%$ ) to osoby w wieku poniżej 65 lat (w tym 414 dzieci; 2,4\%). Ponad połowa leczonych z powodu COVID-19 w szpitalach woj. śląskiego to osoby w wieku 65 i więcej lat $(n=9615$; $56,6 \%$ ). Najmłodsi pacjenci byli w wieku niemowlęcym, a najstarszy pacjent miał 102 lata. Szczegółową strukturę demograficzną przedstawia Rycina 1. Średni wiek zmarłych pacjentów hospitalizowanych z powodu COVID-19 był istotnie większy niż tych którzy przeżyli:

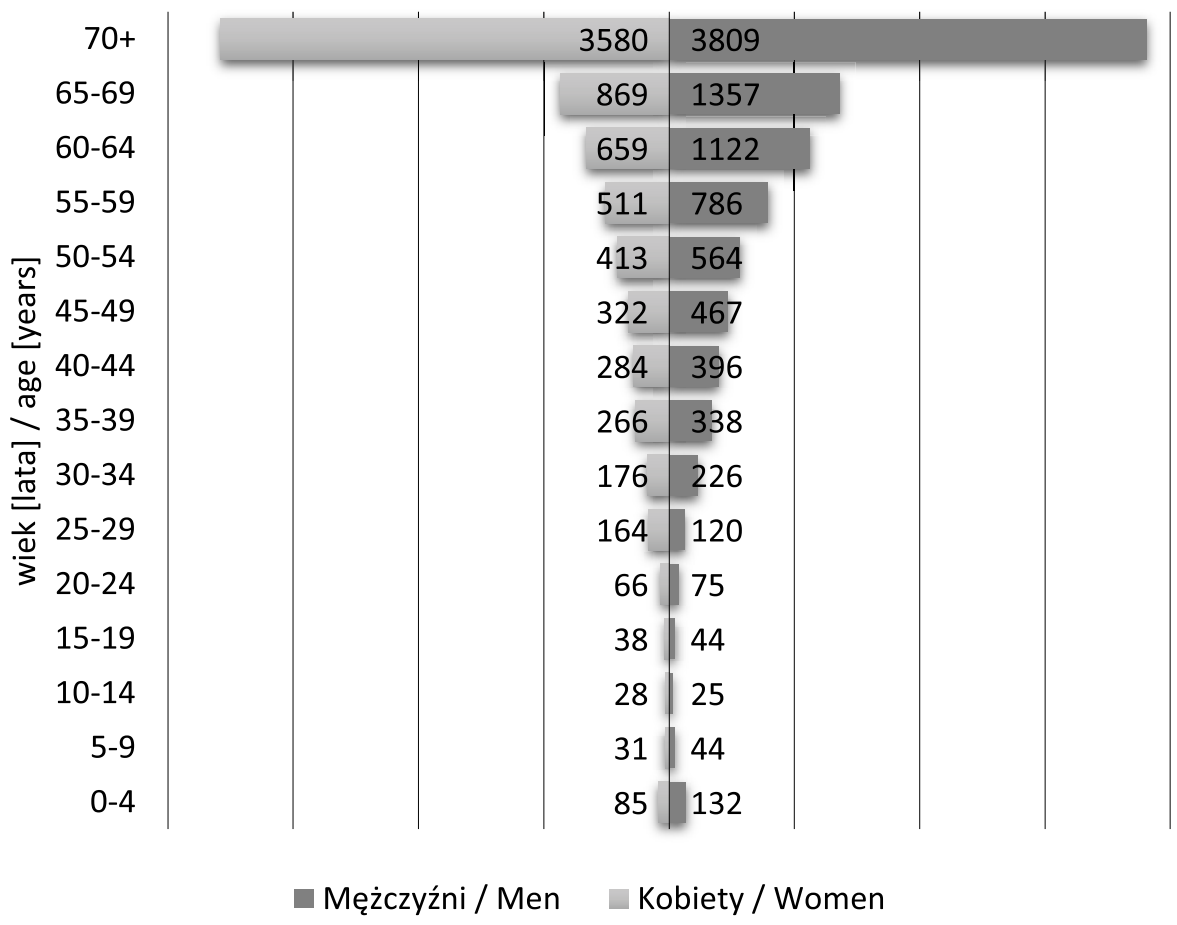

Figure 1. Demographic structure of registered hospitalizations due to COVID-19 in 2020 in the Silesian Voivodeship Rycina 1. Struktura demograficzna rejestrowanych hospitalizacji z powodu COVID-19 w 2020 roku w woj. śląskim 
those who survived: $74.3 \pm 11.5$ years vs $61.9 \pm 18.3$ years; $p<0.001$. The age of the deceased women was significantly higher than deceased men $(76.8 \pm 11.1$ and $72.8 \pm 11.5$ years, respectively; $\mathrm{p}<0.0001$ ).

Table III shows that the majority of patients hospitalized due to COVID-19 did not have comorbidities $(n=7,659 ; 45 \%)$. At the same time, for $16.3 \%$ of patients $(n=2,770)$, at least three comorbidities were diagnosed. It is worth noticing that the percentage of deaths was the largest in the group of patients with three comorbidities and this difference was statistically significant to the percentage of deaths in the groups with no comorbidities or 1-2 comorbidities.
$74,3 \pm 11,5$ lat vs $61,9 \pm 18,3$ lat; $p<0,001$. Wiek zmarłych kobiet był znamiennie większy niż zmarłych mężczyzn (odpowiednio $76,8 \pm 11,1$ oraz $72,8 \pm 11,5$ lat; $p<0,0001$ ).

Tabela III wskazuje, że większość chorych hospitalizowanych z powodu COVID-19 nie posiadała chorób współwystępujących ( $\mathrm{n}=7$ 659; 45\%). Jednocześnie w odniesieniu do $16,3 \%$ pacjentów $(n=2770)$ rozpoznano przynajmniej 3 choroby współtowarzyszące. Warto zwrócić uwagę, że odsetek zmarłych był największy $\mathrm{w}$ grupie pacjentów $\mathrm{z}$ trzema chorobami współistniejącymi i różnica ta była istotna statystycznie względem odsetka zmarłych w grupach z brakiem chorób współistniejących lub 1-2 chorobami towarzyszącymi.

Table III. Number and percentage of patients who survived or died depending on the number of COVID-19 comorbidities in 2020 in Silesian Voivodeship

Tabela III. Liczba i odsetek pacjentów, którzy przeżyli bądź zmarli w zależności od liczby chorób współistniejących z COVID-19 w 2020 roku w woj. śląskim

\begin{tabular}{|c|c|c|c|c|c|}
\hline $\begin{array}{c}\text { Liczba chorób } \\
\text { towarzyszących COVID-19 / } \\
\text { Number of COVID-19 } \\
\text { comorbidities }\end{array}$ & $\begin{array}{l}\text { Brak danych/ } \\
\text { No available } \\
\text { n }\end{array}$ & $\begin{array}{l}\text { Przeżycie / } \\
\text { Survival } \\
\text { n }(\%)\end{array}$ & $\begin{array}{l}\text { Zgon / } \\
\text { Death } \\
\mathrm{n}(\%)\end{array}$ & $\begin{array}{l}\text { Ogółem / } \\
\text { Total } \\
\mathrm{n}(\%)\end{array}$ & $\begin{array}{c}\mathrm{p} / \\
\mathrm{p} \text {-value }\end{array}$ \\
\hline Brak chorób / No diseases & 47 & $6777(88,4)$ & $835(10,9)$ & $7659(100)$ & \multirow{5}{*}{$\mathrm{p}<0,000$} \\
\hline Jedna choroba / One disease & 12 & $3830(87,8)$ & $519(11,9)$ & $4361(100)$ & \\
\hline Dwie choroby / Two diseases & 2 & $1594(72,0)$ & $617(27,9)$ & $2213(100)$ & \\
\hline Trzy choroby / Three diseases & 2 & $1771(63,9)$ & $997(36,0)$ & $2770(100)$ & \\
\hline Ogółem / Total & 63 & $13972(82,2)$ & $2968(17,5)$ & $17003(100)$ & \\
\hline
\end{tabular}

The most frequently registered comorbidities were chronic respiratory diseases J00-J99 and cardiovascular diseases I00-I99, while endocrine disorders including diabetes E00-E99, diseases of the genitourinary system N00-N99, and neoplastic diseases C00-D48 had a much smaller share. The detailed data are presented in Table IV.

The spatial variability of the number of people hospitalized and who died due to COVID-19 was also analyzed. The vast majority of the hospitalized $(\mathrm{N}=16,474 ; 96.9 \%)$ were inhabitants of the Silesian Voivodeship. Among patients treated in Silesian's hospitals were also inhabitants of the neighboring voivodeships: Malopolskie (1.04\%), Opolskie (0.37\%), Lodzkie (0.16\%), and Swietokrzyskie (0.11\%).

Obtained results indicate that the highest number of hospitalizations due to COVID-19 concerned poviats located in the southern part of the Silesian Voivodeship (cieszynski poviat, wodzislawski poviat and the city of Rybnik), as far as the cities of Czestochowa and Katowice (Figure 2). A significantly larger number of hospitalized patients due to COVID-19 was also observed in regions with larger population density (population per $1 \mathrm{~km}^{2}$ ), the Spearman correlation coefficient was $0.68(\mathrm{p}<0.0001)$.
Najczęściej wśród zarejestrowanych chorób współistniejących znajdowały się przewlekłe choroby układu oddechowego J00-J99 i choroby układu krążenia I00-I99, zaś znacznie mniejszy udział miały zaburzenia wydzielania wewnętrznego $\mathrm{z}$ cukrzycą włącznie E00-E99, choroby układu moczowo-płciowego N00-N99, a także choroby nowotworowe C00-D48. Szczegółowe dane przedstawiono w Tabeli IV.

Przeanalizowano również zmienność terytorialną w zakresie liczby osób hospitalizowanych i zmarłych z powodu COVID-19. Zdecydowana większość hospitalizowanych $(\mathrm{N}=16 \quad 474 ; 96,9 \%)$ to mieszkańcy województwa śląskiego. Wśród leczonych w szpitalach naszego województwa znaleźli się także mieszkańcy województw ościennych: małopolskiego $(1,04 \%)$, opolskiego $(0,37 \%)$, łódzkiego $(0,16 \%)$ i świętokrzyskiego $(0,11 \%)$.

Uzyskane wyniki wskazują, że największa liczba hospitalizacji z powodu COVID-19 dotyczyła mieszkańców powiatów zlokalizowanych w południowej części województwa śląskiego (powiat cieszyński, wodzisławski i miasto Rybnik), a także miast Częstochowa i Katowice (Rycina 2). Zaobserwowano również istotnie wyższą liczbę hospitalizowanych z powodu COVID-19 w gminach o większej gęstości zaludnienia (ludność na 
Table IV. Number and percentage of patients with more frequently coexisting diseases, cumulative data in the period from March 01 to December 31, Silesian Voivodeship, 2020

Tabela IV. Liczba i odsetek pacjentów z najczęściej rozpoznaną chorobą towarzyszącą COVID-19, dane skumulowane za okres od 01 marca do 31 grudnia 2020 roku, woj. śląskie

\begin{tabular}{|c|c|c|c|}
\hline \multirow{2}{*}{$\begin{array}{c}\text { Nazwa i kod ICD-10 dla najczęściej występujących } \\
\text { chorób towarzyszących } \\
\text { COVID-19/ } \\
\text { Name and ICD-10 code of more frequently } \\
\text { comorbidities ( }=17003 \text { ) }\end{array}$} & \multicolumn{3}{|c|}{$\begin{array}{c}\text { Liczba i \% pacjentów z rozpoznaną chorobą współistniejącą } \\
- \text { dane skumulowane / } \\
\text { Number and percentage of hospitalized patients with } \\
\text { comorbidities - cumulative data }\end{array}$} \\
\hline & $\begin{array}{l}\text { Pierwsza choroba / } \\
\text { The first disease } \\
\mathrm{N}=9343\end{array}$ & \begin{tabular}{|c|} 
Druga choroba / \\
The second disease \\
$\mathrm{N}=4983$
\end{tabular} & $\begin{array}{l}\text { Trzecia choroba / } \\
\text { The third disease } \\
\text { N=2771 }\end{array}$ \\
\hline $\begin{array}{l}\text { Choroby układu oddechowego (J00-J99) / } \\
\text { Diseases of the respiratory system }\end{array}$ & $4195(24,6)$ & $1856(10,9)$ & $964(5,7)$ \\
\hline $\begin{array}{l}\text { Choroby układu krążenia (I00-I99) / } \\
\text { Diseases of the circulatory system }\end{array}$ & $2171(12,7)$ & $1588(9,3)$ & $861(5,1)$ \\
\hline $\begin{array}{l}\text { Zaburzenia wydzielania wewnętrznego, stanu } \\
\text { odżywienia i przemian metabolicznych, w tym } \\
\text { cukrzyca (E00-E99)/ } \\
\text { Endocrine, nutritional and metabolic diseases }\end{array}$ & $511(3,0)$ & $557(3,3)$ & $362(2,1)$ \\
\hline $\begin{array}{c}\text { Choroby układu moczowo-płciowego (N00-N99) / } \\
\text { Diseases of the genitourinary system }\end{array}$ & $554(3,3)$ & $213(1,3)$ & $147(0,9)$ \\
\hline $\begin{array}{c}\text { Objawy, cechy chorobowe R00-R99/ } \\
\text { Symptoms, signs and abnormal clinical and laboratory } \\
\text { findings }\end{array}$ & $412(2,4)$ & $112(0,7)$ & $66(0,4)$ \\
\hline $\begin{array}{c}\text { Choroby nowotworowe (C00-D48) / } \\
\text { Neoplasms }\end{array}$ & $279(1,6)$ & $120(0,7)$ & $56(0,3)$ \\
\hline
\end{tabular}

The value of the cumulative hospitalized morbidity in the entire period (from March to December) for the Silesian Voivodeship was at the level of 366.7/100,000 inhabitants. The highest crude rates per 100,000 inhabitants were recorded in the following poviats: cieszynski (1,124.3), rybnicki (841.8), raciborski (428.3), wodzislawski (595.2), and in the cities of Rybnik (1,099.7), Zory (434.4), Czestochowa (408.2). The standardized hospitalized morbidity rate was 250.6/100,000 inhabitants, additionally, the highest values were recorded in Rybnik (878.2/100,000), cieszynski (745.5/100,000), and rybnicki poviat $(685.6 / 100,000)$. The detailed data are presented in Figure 3.

It is worth noticing that the largest number of deaths concerned patients hospitalized in bigger cities: Czestochowa, Gliwice, Katowice, Rybnik, and wodzislawski, cieszynski poviats, where a high level of hospitalization was also noted. Older people over the age of 65 , died more frequently. In this group, in-hospital mortality was at the level of $29.6 \%$, while in the group of people under the age of 65 was at the level of $10.7 \%$. The percentage of deaths among hospitalized patients due to COVID-19 in 2020 for the entire Silesian Voivodeship was $17.4 \%$ and was the highest in the following cities: Gliwice (28.5\%), Myslowice (26.8\%), Tychy (24.5\%), Bytom (24.2\%), and lubliniecki poviat $(25.7 \%)$. It was also observed that in most poviats (33 out of 36) the in-hospital mortality rate exceeded 15\% (Figure 4).
1 km²), współczynnik korelacji R’ Spearmana kształtował się na poziomie $0,68(\mathrm{p}<0,0001)$.

Wartość skumulowanej chorobowości hospitalizowanej w całym badanym okresie (od marca do grudnia) dla województwa śląskiego kształtowała się na poziomie 366,7/100 000 mieszkańców. Najwyższe surowe współczynniki w przeliczeniu na 100000 mieszkańców odnotowano w powiatach: cieszyńskim $(1$ 124,3), rybnickim $(841,8)$, raciborskim $(428,3)$, wodzisławskim $(595,2)$ oraz w miastach Rybnik $(1099,7)$, Żory $(434,4)$, Częstochowa $(408,2)$. Standaryzowany współczynnik chorobowości hospitalizowanej kształtował się na poziomie 250,6/100 000 mieszkańców. Również w tym przypadku najwyższe wartości dotyczyły powiatów i miast na prawach powiatu: Rybnik $(878,2 / 100000)$, cieszyńskiego $(745,5 / 100000)$ i rybnickiego $(685,6 / 100000)$. Szczegółowe dane prezentuje Rycina 3.

Jeśli chodzi o zgony to warto odnotować, że największa liczba dotyczyła pacjentów hospitalizowanych w dużych miastach: Częstochowa, Gliwice, Katowice, Rybnik oraz powiatach: wodzisławskim i cieszyńskim, w których notowano również wysoki poziom hospitalizacji. Częściej umierały osoby starsze, w wieku powyżej 65 lat. W grupie tej śmiertelność wewnątrzszpitalna kształtowała się na poziomie $29,6 \%$, podczas gdy w grupie osób w wieku poniżej 65 lat - na poziomie $10,7 \%$. Odsetek zgonów wśród hospitalizowanych z powodu COVID-19 w 2020 roku dla całego województwa śląskiego wynosił 17,4\% i był największy w miastach: Gliwice (28,5\%), Mysłowice (26,8\%), Tychy $(24,5 \%)$, 


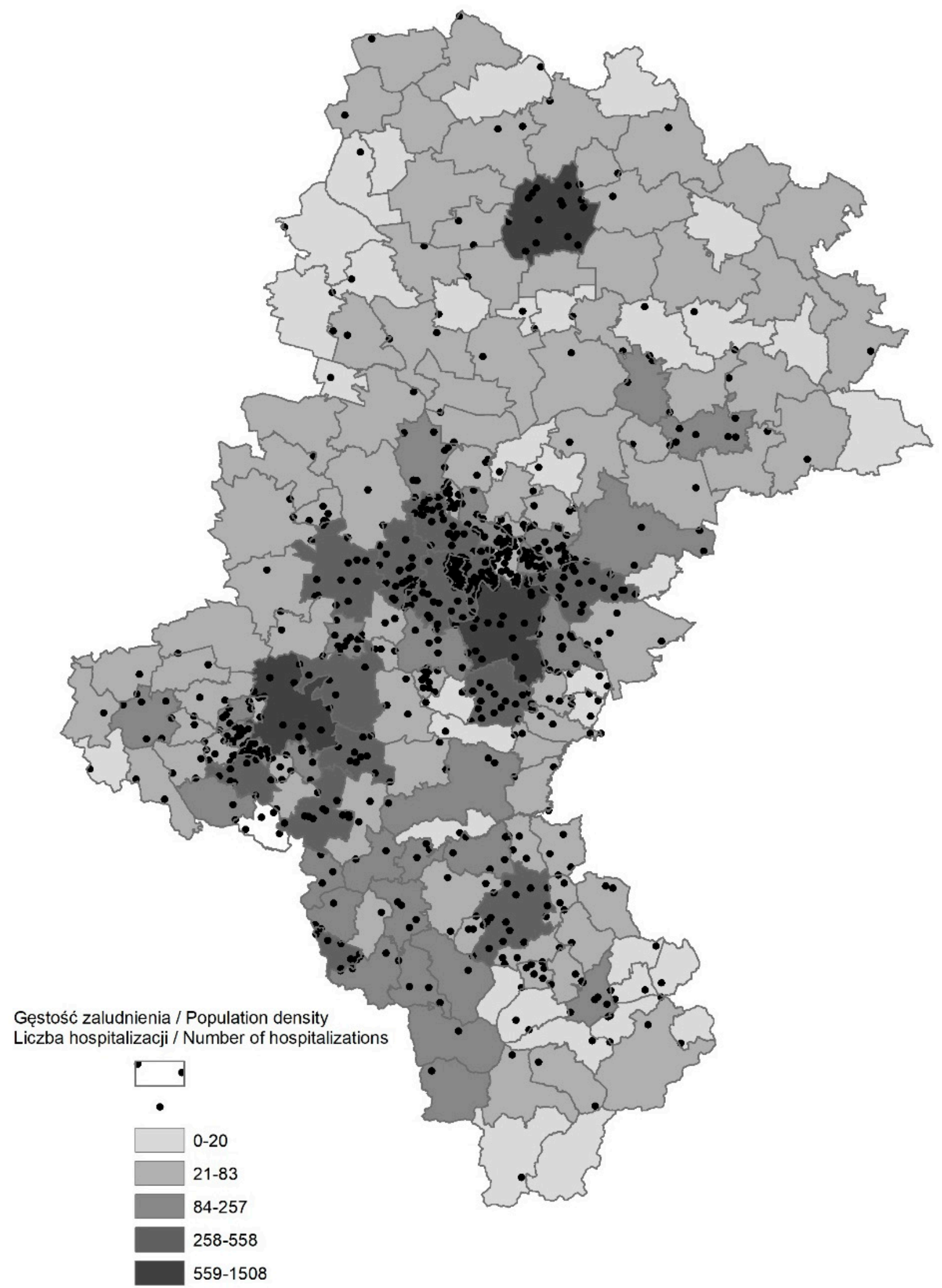

Figure 2. Number of patients hospitalized due to COVID-19 in 2020 in the Silesian Voivodeship according to population density

Rycina 2. Liczba pacjentów hospitalizowanych z powodu COVID-19 w 2020 roku w woj. śląskim z uwzględnieniem gęstości zaludnienia 


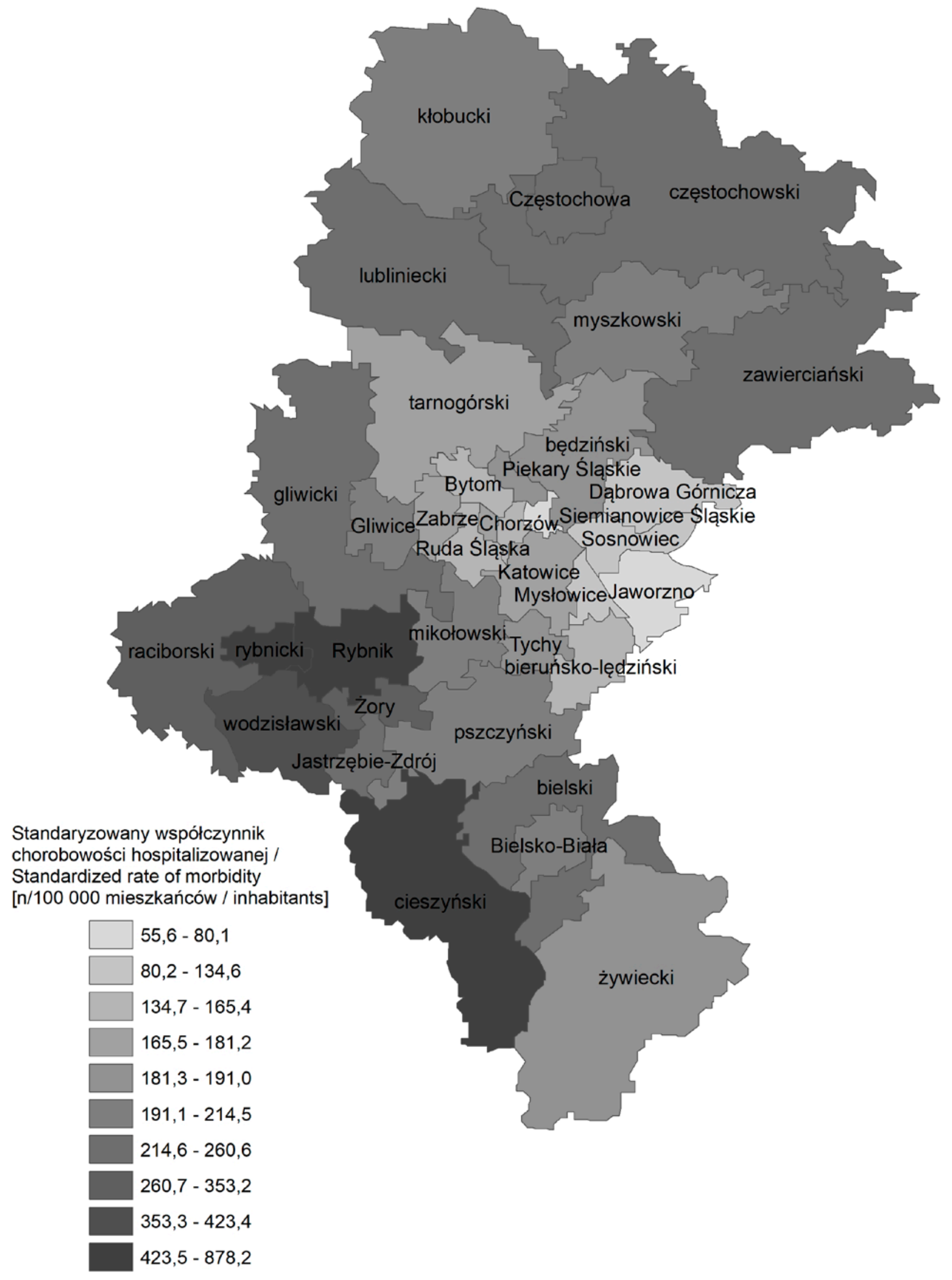

Figure 3. Standardized rate of morbidity (n/100,000) due to COVID-19 in hospitals of the Silesian Voivodeship in 2020 by poviats

Rycina 3. Standaryzowany współczynnik chorobowości hospitalizowanej (n/100 000) z powodu COVID-19 w szpitalach woj. śląskiego w 2020 roku według powiatów 


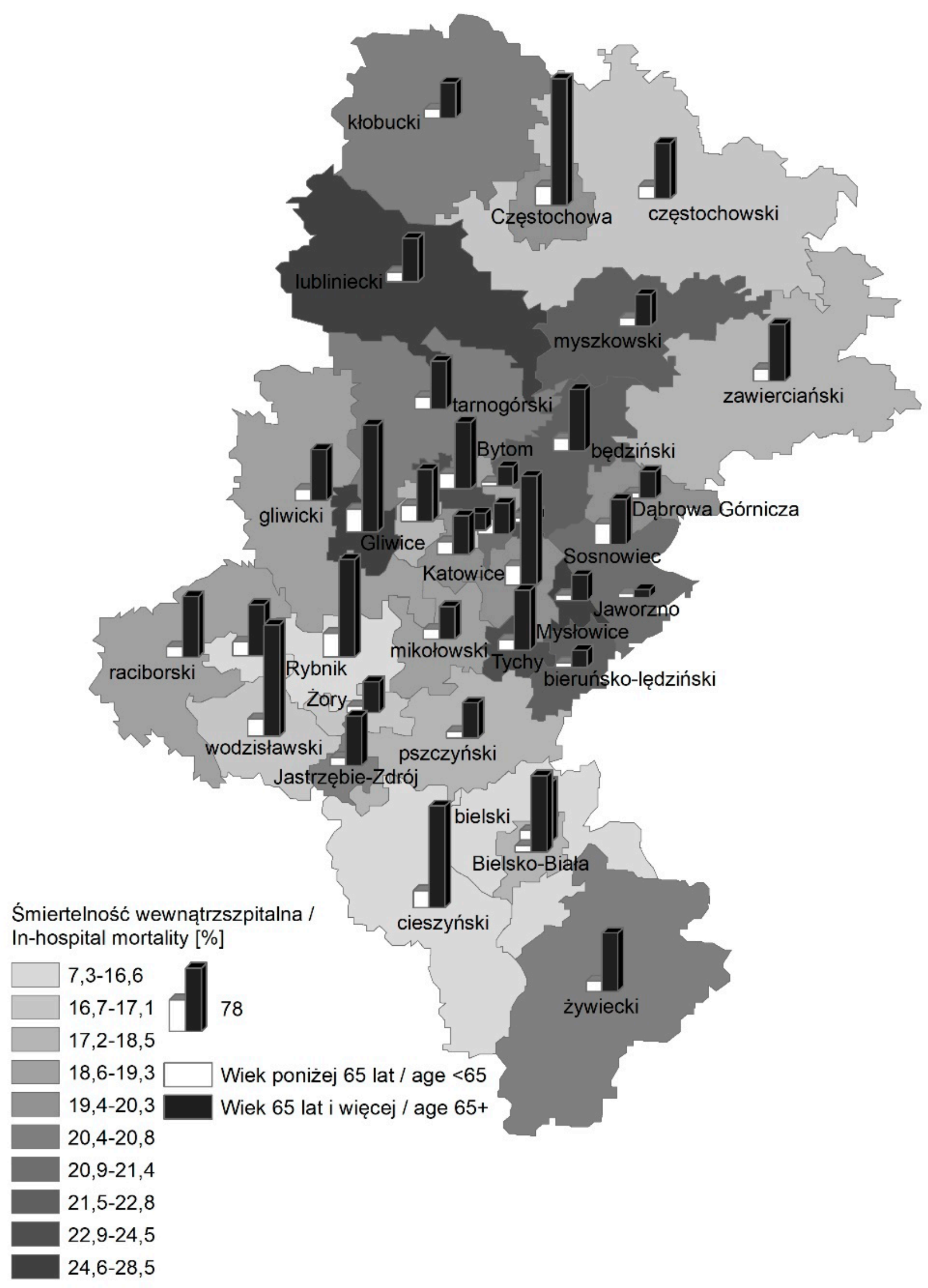

Figure 4. In-hospital mortality (\%) due to COVID-19 in the Silesian Voivodeship in 2020 by poviats and age of patients Rycina 4. Śmiertelność wewnątrzszpitalna (\%) z powodu COVID-19 w woj. śląskim w 2020 roku według powiatów i wieku 


\section{DISCUSSION}

To assess the epidemiological situation of infectious diseases, we usually use the incidence rate, which describes the number of new events that occur in a population in a specified period (10). Because of the serious course of COVID-19, which, in many cases, requires hospitalization, it is also important to analyze in-hospital morbidity and in-hospital mortality. Such analysis allows us to estimate the costs of the treatment, enables the assessment of the effectiveness of the therapeutic process, and helps develop effective actions in the implemented health policy.

The analysis of secondary epidemiological data on hospitalized morbidity and in-hospital mortality in the period from March to December 2020, revealed significant spatial variability but also significant temporal changes related to the season. The obtained results were published in previous publications reflecting the situation of the first wave of the epidemic (11) and related to the period of summer of 2020 (12). Nevertheless, usually in autumn, the number of cases of viral diseases such as seasonal flu (13) increases. As well, the increase in the number of deaths due to cardiovascular and respiratory causes in response to the deterioration of the aerosanitary quality of atmospheric air is observed (14). Those arguments justify that a proper epidemiological assessment of COVID-19 is necessary to present the situation throughout the entire year.

It has been shown that, while the number of hospitalized patients with high in-hospital mortality of over 24\% was increasing from month to month in Silesian Voivodeship in the spring, the situation improved significantly in the summer. Mortality decreased below 7\%, and also a lower number of patients required hospitalization. A rapid increase in the number of COVID-19 patients requiring hospitalization was noted in autumn, with the accompanying large percentage (over 24\%) of deaths among patients. Although there is no clear explanation of this observation, it cannot be excluded that it is the effect of the increased spread of SARS-CoV-2 virus among younger people, related to the beginning of the academic year and the return of students to the university (15). Despite the sanitary regime applied in schools and universities, an increase in the number of infections was observed in younger age groups (16). Our previous observations confirmed that positive results of the IgG antibodies SARS-CoV-2 test were more frequently detected in the group of adolescents aged 15-18 (27.3\%) and 19-25 (17.4\%) (16).

Moreover, each autumn season is related to the increase of the number of patients with respiratory
Bytom $(24,2 \%)$ oraz powiecie lublinieckim $(25,7 \%)$. Zaobserwowano również, iż w większości powiatów (33 spośród 36) wskaźnik śmiertelności wewnątrzszpitalnej przekraczał 15\% (Rycina 4).

\section{DYSKUSJA}

W ocenie sytuacji epidemiologicznej chorób zakaźnych odwołujemy się zazwyczaj do współczynnika zapadalności, który opisuje liczbę nowych zachorowań w populacji narażonej na ryzyko zachorowania (10). Z uwagi na poważny przebieg COVID-19, w wielu przypadkach wymagający hospitalizacji, nie mniej ważne jest również poddanie analizie chorobowości szpitalnej i śmiertelności wewnątrzszpitalnej. Taka ocena pozwala bowiem oszacować koszty stosowanego leczenia, umożliwia ocenę efektywności procesu terapeutycznego, a tym samym daje podstawy do opracowania skutecznych działań w zakresie realizowanej polityki zdrowotnej.

Analiza wtórnych danych epidemiologicznych dotyczących chorobowości hospitalizowanej i śmiertelności wewnątrzszpitalnej w okresie od marca do grudnia 2020 r. ujawniła znaczne zróżnicowanie terytorialne, ale także istotne zmiany w czasie związane z porą roku. Uzyskane wyniki były już przedmiotem wcześniejszych publikacji odzwierciedlających sytuację tzw. pierwszej fali epidemii (11), a także dotyczyły okresu lata $2020 \mathrm{r}$. (12). Niemniej jednak to zazwyczaj jesienią mamy do czynienia ze wzrostem liczby zachorowań na choroby wirusowe takie, jak grypa sezonowa (13), a także wzrost liczby zgonów z przyczyn krążeniowo-oddechowych w odpowiedzi na pogorszenie jakości aerosanitarnej powietrza atmosferycznego (14). Uznano, że dla właściwej oceny epidemiologicznej COVID-19 niezbędne jest ukazanie sytuacji w skali całego roku.

Wykazano, że o ile wiosną mieliśmy w woj. śląskim wzrastającą z miesiąca na miesiąc liczbę chorych hospitalizowanych przy wysokiej śmiertelności wewnątrzszpitalnej sięgającej powyżej $24 \%$, to w okresie letnim sytuacja znacznie się poprawiła. Śmiertelność spadła poniżej $7 \%$, a także mniejsza liczba chorych wymagała leczenia szpitalnego. Jesienią zarejestrowano z kolei gwałtowny wzrost liczby pacjentów z COVID-19 wymagających hospitalizacji i towarzyszył mu wysoki odsetek zgonów wśród chorych, który ponownie przekroczył wartość $24 \%$. Choć brak jest jednoznacznego wytłumaczenia tej obserwacji, nie można wykluczyć, iż jest to efekt wzmożonego rozprzestrzeniania się wirusa SARS-CoV-2 wśród osób młodszych, wynikającego między innymi z początku roku akademickiego i powrotu studentów do uczelni (15). Pomimo reżimu sanitarnego stosowanego na terenie obiektów szkolnych i uniwersyteckich obserwowano postępujący wzrost liczby zakażeń w młodszych grupach wiekowych (16). 
viral infections, including influenza, and with symptoms of immune system weakness, which results in an overloading Polish health care system $(13,17)$. Our observations indicate that vaccination against seasonal influenza may be an independent factor that reduces the risk of positive $\operatorname{IgG}$ antibody test so it may be a factor protecting of a high frequency of SARS-CoV-2 infections (18). Official data suggest that the percentage of people vaccinated against seasonal flu in Poland is the largest over the age of 65 . It was $15.1 \%$, with a value close to $2 \%$ in younger age groups, in 2019/2020 (19). This can indirectly explain smaller rates of SARS-CoV-2 infection in the elderly who at the same time most often followed the recommendations related to maintaining social distance.

During the entire observation period, men were more often hospitalized than women, most people over 65 , although newborns were also among the patients. Deaths of COVID-19 hospitalized patients mostly concerned older people, over the age of 70 . This observation is in line with the observations of other authors (20-23).

Additionally, very important observation suggests that the highest risk of death concerned patients with three comorbidities, among which cardiovascular and respiratory diseases, and endocrine disorders, including diabetes, were predominated. Regardless of the study region, the occurrence of comorbidities in older patients was a significant factor leading to a more severe course of the disease and thus increased the risk of death $(24,25)$. As in the first half of the year, in autumn, chronic respiratory and cardiovascular diseases were dominated. Endocrine diseases, including diabetes, diseases of the genitourinary system, and neoplasms were rarer.

The spatial variability of both hospitalized morbidity and in-hospital mortality is a separate issue. The largest crude rates per 100,000 inhabitants were recorded in the following poviats: cieszynski $(1,124.3)$, rybnicki (841.8), raciborski (428.3), wodzislawski (595.2) and in the cities of Rybnik $(1,099.7)$, Zory (434.4), Czestochowa (408.2). It is difficult to explain this difference based on a descriptive study. However, some explanations can be related to the intense population movement in poviats located close to the border of the country, as well as in the employment of people in large production plants, including those related to active coal mining. In the poviats rybnicki, Rybnik, and Zory, younger people were hospitalized most frequently, while in other regions elderly people (over 65 years of age) were hospitalized more often (11). On the other hand, the pilgrimage movement to a well-known religious center in Czestochowa can impact a higher number of hospitalized people
Warto przytoczyć $\mathrm{w}$ tym miejscu obserwacje poczynione w ramach badania poziomu przeciwciał anty-SARSCoV-2 w klasie IgG przeprowadzonego jesienią $2020 \mathrm{r}$. w populacji woj. śląskiego. Uzyskane wyniki potwierdziły, że odsetek pozytywnych testów był największy właśnie w grupie młodzieży w wieku 15-18 lat (27,3\%) oraz 19-25 lat (17,4\%) (16).

Ponadto okres jesieni zawsze sprzyja wzrostowi liczby chorych $\mathrm{z}$ infekcjami wirusowymi układu oddechowego, w tym grypy, oraz z objawami pogorszenia sprawności układu odpornościowego, co skutkuje nadmiernym obciążeniem coraz mniej wydolnego systemu opieki zdrowotnej $(13,17)$. Obserwacje własne wskazują, że zaszczepienie przeciwko grypie sezonowej może być niezależnym czynnikiem mniejszego ryzyka uzyskania dodatniego wyniku testu w kierunku przeciwciał IgG, a więc może być okolicznością sprzyjającą mniejszej częstości zakażeń SARS-CoV-2 (18). Oficjalne dane sugerują, że odsetek zaszczepionych przeciwko grypie sezonowej jest w Polsce największy u osób po 65 roku życia. W sezonie 2019/2020 wynosił on $15,1 \%$ przy wartości zbliżonej do $2 \% \mathrm{w}$ młodszych grupach wiekowych (19). To może w pewien sposób tłumaczyć mniejsze wskaźniki zakażeń wirusem SARS-CoV-2 właśnie u osób starszych, które jednocześnie najczęściej przestrzegały zaleceń związanych z utrzymywaniem dystansu społecznego.

W całym okresie obserwacji częściej hospitalizowano mężczyzn niż kobiety, zazwyczaj były to osoby po 65 roku życia, choć wśród pacjentów znajdowały się także noworodki. W trakcie całego roku zgony hospitalizowanych z powodu COVID-19 dotyczyły przede wszystkim starszych pacjentów, po 70 roku życia. Obserwacja ta jest zbieżna $\mathrm{z}$ danymi rejestrowanymi przez autorów prac z innych ośrodków badawczych (20-23). Przy istotnym trendzie rosnącym średniej wieku wszystkich pacjentów hospitalizowanych stwierdzono niemal stały poziom wieku osób zmarłych w szpitalach.

Dodatkowo zwrócono uwagę, że największe ryzyko zgonu dotyczyło pacjentów z trzema chorobami współistniejącymi, wśród których dominowały choroby układu krążenia, układu oddechowego i zaburzenia wydzielania wewnętrznego z cukrzycą włącznie. Niezależnie od regionu badań wykazano, że obecność chorób współistniejących u starszych pacjentów była okolicznością prowadzącą do cięższego przebiegu choroby i tym samym zwiększała ryzyko zgonu $(24,25)$. Podobnie, jak w pierwszym półroczu, jesienią w grupie chorób wspólistniejących dominowały przewlekłe choroby układu oddechowego i układu krążenia. Mniejszy udział miały choroby wydzielania wewnętrznego z cukrzycą włącznie, choroby układu moczowo-płciowego oraz nowotwory.

Odrębną kwestią jest zróżnicowanie terytorialne zarówno chorobowości hospitalizowanej, jak i śmier- 
in this poviat. Moreover, it was noted that a higher number of hospitalized patients due to COVID-19 may be related to population density, Spearman's R' correlation coefficient was at the level of 0.68 and was statistically significant $(\mathrm{p}<0.001)$.

The mentioned spatial diversity of in-hospital mortality is also difficult to explain without analytical methods of epidemiology. One of the possible hypotheses may be the diversity resulting from the different availability of necessary medical services and highly specialized medical equipment (like respirators). The highest number of deaths concerned patients hospitalized in bigger cities: Czestochowa, Gliwice, Katowice, Rybnik, and poviats: wodzislawski and cieszynski. On the other hand, the largest percentage of deaths among COVID-19 hospitalized in 2020 was noted in Gliwice (28.5\%), Myslowice (26.8\%), Tychy (24.5\%), Bytom (24.2\%), and lubliniecki poviat (25.7\%). The situation can be probably related to the localization of singlename COVID-19 hospitals in these poviats. It cannot be excluded that this was related to more severe cases of patients and a worse prognosis for survival.

In conclusion, it should be stated that the secondary epidemiological data collected based on the MZ/Szp11 form of the general hospital statistical card are an interesting source of public health information in Poland. Data help to recognize needs related to the COVID-19 hospitalization in one of the most densely populated regions of the country. They allow tracking seasonal changes and recognizing spatial variability of hospitalized morbidity and in-hospital mortality. They help to identify risk or modifier factors (sex, age, and health status of patients) and assess the relationship with prognosis of mode discharge. Despite some limitations related to the secondary character of data, we conclude that they are very useful in public health to recognize the new hazard, like the COVID-19 epidemic. Additionally, the completeness of the data in the Silesian Voivodeship is actually at the level of $99.9 \%(4,26)$, therefore we believe that the presented data are reliable.

\section{CONCLUSIONS}

Both hospitalized morbidity and in-hospital mortality due to COVID-19 showed high variability in the subsequent months of 2020. A higher number of patients and deaths occurred in autumn. There was also a significant spatial diversity of both assessed rates, the worst situation concerned densely populated poviats and cities. telności wewnątrzszpitalnej w badanym regionie. Najwyższe współczynniki w przeliczeniu na 100000 mieszkańców odnotowano w powiatach: cieszyńskim (1 124,3), rybnickim $(841,8)$, raciborskim $(428,3)$, wodzisławskim $(595,2)$ oraz w miastach Rybnik $(1099,7)$, Żory $(434,4)$, Częstochowa $(408,2)$. Trudno wytłumaczyć to zróżnicowanie na gruncie badania opisowego, jednakże pewnego wyjaśnienia można doszukiwać się w intensywnym ruchu ludności w związku z lokalizacją powiatów w rejonie przygranicznym, ale także z zatrudnieniem ludzi w dużych zakładach produkcyjnych, w tym związanych z wydobyciem węgla kamiennego. Właśnie na południu województwa zlokalizowane są czynne kopalnie węgla kamiennego a dodatkowo w powiatach rybnickim, Rybniku i Żorach hospitalizowano raczej osoby młodsze, podczas gdy w pozostałych regionach hospitalizowano więcej osób starszych (powyżej 65 r.ż.) (11). Nie można także wykluczyć, iż ruch pielgrzymkowy do znanego ośrodka religijnego w Częstochowie jest przyczyną większej liczby hospitalizowanych w tym mieście i całym powiecie. Zauważono ponadto, że większa liczba hospitalizowanych z powodu COVID-19 może mieć związek z gęstością zaludnienia, współczynnik korelacji R' Spearmana kształtował się na poziomie $0,68 \mathrm{i}$ był istotny statystycznie $(\mathrm{p}<0,001)$.

Wspomniane zróżnicowanie terytorialne śmiertelności wewnątrzszpitalnej także trudno wytłumaczyć bez zastosowania metod epidemiologii analitycznej. Jedną z potencjalnych hipotez może być zróżnicowanie wynikające $z$ różnej dostępności do niezbędnych świadczeń medycznych i wysoko specjalistycznej aparatury medycznej (respiratory). Największa liczba zgonów dotyczyła pacjentów hospitalizowanych w dużych miastach: Częstochowa, Gliwice, Katowice, Rybnik oraz powiatach: wodzisławskim i cieszyńskim. Z kolei największy odsetek zgonów wśród hospitalizowanych z powodu COVID-19 w 2020 roku dotyczył miast: Gliwice (28,5\%), Mysłowice (26,8\%), Tychy $(24,5 \%)$, Bytom $(24,2 \%)$ oraz powiatu lublinieckiego $(25,7 \%)$. Warto podkreślić, że w wymienionych miastach funkcjonowały szpitale jednoimienne, w których hospitalizowano najcięższe przypadki COVID-19 i nie można wykluczyć, że miało to związek z gorszym rokowaniem przeżycia pacjentów.

W podsumowaniu należy stwierdzić, że wtórne dane epidemiologiczne gromadzone na podstawie formularza MZ/Szp-11 karty statystycznej szpitalnej ogólnej są interesującym źródłem informacji pozwalającym na rozpoznanie sytuacji COVID-19 w jednym z najgęściej zaludnionych regionów Polski. Ukazują one dynamikę świadczeń zdrowotnych udzielanych pacjentom hospitalizowanym $\mathrm{w}$ poszczególnych miesiącach i porach roku. Jednocześnie umożliwiają śledzenie terytorialnego zróżnicowania w powiatach woj. śląskiego zarówno chorobowości hospitalizowanej, jak i śmiertelności 


\section{REFERENCES}

1. World Health Organization (Internet). WHO Director-General's remarks at the media briefing on 2019-nCoV on 11 February 2020 (cited 2021 July 1). Available from: https://www.who.int/ director-general/speeches/detail/who-directorgeneral-s-remarks-at-the-media-briefing-on-2019ncov-on-11-february-2020? fbclid=IwAR0XX5gg WqCFHFay5teFe5j7FQj2tdyl38J65NKqrWstxHR L-ltt1fvIX6A.

2. Dziennik Ustaw Rzeczypospolitej Polskiej (Internet). Dziennik Ustaw z dnia 20 marca 2020 r., Poz. 491, Rozporządzenie Ministra Zdrowia z dnia 20 marca 2020 r. w sprawie ogłoszenia na obszarze Rzeczypospolitej Polskiej stanu epidemii (cited 2021 July 1). Available from: http://prawo.sejm.gov.pl/isap.nsf/download.xsp/ WDU20200000491/O/D20200491.pdf

3. Śląski Urząd Wojewódzki w Katowicach, Wydział Zdrowia - Oddział do Spraw Monitorowania, Analiz i Statystyki Medycznej (Internet). Zadania realizowane przez Zespół med. chorobowości hospitalizowanej (cited 2021 July 1). Available from: https://www.katowice.uw.gov.pl/wydzial/ wydzial-zdrowia/zadania-zespolu-do-sprawchorobowosci-hospitalizowanej.

4. Dziennik Ustaw Rzeczypospolitej Polskiej (Internet). Dziennik Ustaw 2993. Poz. 837. 2017 rok. MZ/Szp-11 karta statystyczna szpitalna ogólna (cited 2021 July 1). Available from: https:// www.katowice.uw.gov.pl/download/1899.pdf.

5. Urząd Statystyczny w Katowicach (Internet). Ludność, ruch naturalny i migracje w województwie śląskim w 2019 r. (cited 2021 July 1). Available from: https://katowice.stat.gov. $\mathrm{pl} /$ publikacje-i-foldery/ludnosc/ludnosc-ruchnaturalny-i-migracje-w-wojewodztwie-slaskim-w2019-r-,2,18.html.

6. IV Kongres Wyzwań Zdrowotnych (Internet). Polski szpital 2019 - lecznictwo stacjonarne w polskim systemie ochrony zdrowia. Katowice 07.03.2019 (cited 2021 July 1). Available from: https://www.hccongress.pl/2019/pl/panel/2989. html.

7. Prevalence and Risk Factors of COVID-19 in the Upper Silesian Agglomeration (EpiSARS2) (Internet). ClinicalTrials.gov Identifier: NCT04627623 (cited 2021 July 1). Available from: https://clinicaltrials.gov/ct2/show/NCT04627623.

8. Bank Danych Lokalnych. Główny Urząd Statystyczny (Internet). Stan ludności (stan na 31 grudnia 2020 r.) (cited 2021 July 1). Available from: https://bdl.stat.gov.pl/BDL/dane/podgrup/ temat.

9. World Health Organization (Internet). Age Standarization of Rates: A new WHO Standard wewnątrzszpitalnej. Pozwalają rozpoznać uwarunkowania związane z płcią i wiekiem chorych, a zarazem ułatwiają ocenę rokowania przy uwzględnieniu chorób towarzyszących. Pomimo wtórnego charakteru danych są ważnym źródłem informacji w zdrowiu publicznym, niezbędnym do oceny rzeczywistych potrzeb zdrowotnych związanych z nowym zagrożeniem epidemiologicznym, jakim jest COVID-19. Warto nadmienić, iż w województwie śląskim wszystkie jednostki lecznicze wskazane w przepisach $(4,26)$ przedstawiają omawiane sprawozdania dotyczące hospitalizacji, a kompletność danych kształtuje się na poziomie $99,9 \%$, zatem należy uznać źródło za wiarygodne.

\section{WNIOSKI}

Zarówno chorobowość hospitalizowana, jak i śmiertelność wewnątrzszpitalna z powodu COVID-19 wykazywały dużą zmienność w kolejnych miesiącach 2020 roku. Największa liczba chorych i zgonów dotyczyła jesieni. Zaobserwowano także istotne zróżnicowanie terytorialne obydwu omawianych współczynników, najgorsza sytuacja dotyczyła powiatów i miast gęsto zaludnionych.

(cited 2021 July 1). Available from: https://www. who.int/healthinfo/paper31.pdf.

10. Beaglehole R, Bonita R, Kjellstrom T. Podstawy epidemiologii. Łódź: Wydawnictwo Instytutu Medycyny Pracy; 2002.

11. Kowalska M, Niewiadomska E. Chorobowość i śmiertelność wśród osób hospitalizowanych z powodu COVID-19 w województwie śląskim w trakcie pierwszej fali zakażeń. Hygeia Public Health 2020;55(3):115-120.

12. Kowalska M, Niewiadomska E. Chorobowość i śmiertelność wewnątrzszpitalna $z$ powodu COVID-19 w województwie śląskim w trakcie miesięcy letnich 2020 roku. Hygeia Public Health 2020;55(4):161-166.

13. Kowalska M. Aktualna sytuacja epidemiologiczna grypy w województwie śląskim. Ann Acad Med. Siles 2021;75:33-40.

14. Kowalska M. Wpływ krótkoterminowych zmian stężeń drobnego pyłu zawartego $\mathrm{w}$ powietrzu atmosferycznym na dobowa umieralność i chorobowość $\mathrm{z}$ przyczyn krążeniowo-oddechowych w populacji mieszkańców aglomeracji miejsko-przemysłowej (aglomeracja katowicka). Katowice: Śląski Uniwersytet Medyczny w Katowicach (rozprawa habilitacyjna);2011.

15. Nauka w Polsce. Nauczanie w semestrze zimowym na uczelniach - głównie w trybie mieszanym. (cited 2021 September 17). Available 
from: https://naukawpolsce.pap.pl/aktualnosci/ news\%2C83797\%2Cnauczanie-w-semestrzezimowym-na-uczelniach-glownie-w-trybiemieszanym.html.

16. Zejda JE, Brożek GM, Kowalska $M$, et al. Seroprevalence of Anti-SARS-CoV-2 Antibodies in a Random Sample of Inhabitants of the Katowice Region, Poland. Int J Environ Res Public Health 2021;18(6):3188.

17. NIZP-PZH (Internet). Zachorowania i podejrzenia zachorowań na grypę w Polsce. Liczba zachorowań i podejrzeń zachorowań na grypę $\mathrm{w}$ sezonach (wrzesień-sierpień) 1974/5 - 2018/19 wg miesięcy (cited 2021 July 1). Available from: http://wwwold. pzh.gov.pl/oldpage/epimeld/grypa/index.htm.

18. Kowalska M, Niewiadomska E, Barański K, et al. Association between Influenza Vaccination and Positive SARS-CoV-2 IgG and IgM Tests in the General Population of Katowice Region, Poland. Vaccines 2021;9(5):415.

19. NIZP-PZH (Internet). Jaki jest poziom zaszczepienia przeciw grypie w Polsce (cited 2021 July 1). Available from: https://szczepienia. pzh.gov.pl/faq/jaki-jest-poziom-zaszczepieniaprzeciw-grypie-w-polsce/.

20. Ho FK, Petermann-Rocha F, Gray SR, et al. Is older age associated with COVID-19 mortality in the absence of other risk factors? General population cohort study of 470,034 participants. PloS One 2020;15(11):e0241824.

21. Imam Z, Odish F, Gill I, et al. Older age and comorbidity are independent mortality predictors in a large cohort of 1305 COVID-19 patients in Michigan, United States. J Intern Med 2020;288(4):469-476.
22. Rapp JL, Lieberman-Cribbin W, Tuminello S, Taioli E. Male Sex, Severe Obesity, Older Age, and Chronic Kidney Disease Are Associated With COVID-19 Severity and Mortality in New York City. Chest 2021;159(1):112-115.

23. Biagi A, Rossi L, Malagoli A, et al. Clinical and epidemiological characteristics of 320 deceased patients with Covid-19 in an Italian Province: a retrospective observational study. J Med Virol 2020;92(11):2718-2724.

24. Williamson EJ, Walker AJ, Bhaskaran K, et al. Factors associated with COVID-19-related death using OpenSAFELY. Nature 2020;584:430-436. Doi: 10.1038/s41586-020-2521-4.

25. Pena JE, Rascón-Pacheco RA, Ascencio-Montiel IJ, et al. Hypertension, Diabetes and Obesity, Major Risk Factors for Death in Patients With COVID-19 in Mexico. Arch Med. Res 2020;S01884409(20)32243-8.

26. Biuletyn Informacji Publicznej. Działalność statystyki publicznej - Badania statystyczne. (cited 2021 September 17). Available from: https:// bip.stat.gov.pl/dzialalnosc-statystyki-publicznej/ badania-statystyczne/pbssp-na-2018/czescdruga/257,zestaw.html.

\section{Received: 26.07.2021}

Accepted for publication: 04.10.2021

Otrzymano: 26.07.2021 r.

Zaakceptowano do publikacji: 04.10.2021 r.

\section{Address for correspondence:}

Adres do korespondencji:

Prof. Małgorzata Kowalska

Śląski Uniwersytet Medyczny w Katowicach

Wydział Nauk Medycznych

ul. Medyków 18, 40-752 Katowice

e-mail:mkowalska@sum.edu.pl 